\title{
Improvement of the stainless steel electropolishing process by organic additives
}

\author{
Pawel Lochynski ${ }^{1, *}$, Maciej Kowalski ${ }^{2}$, Bogdan Szczygiel $^{3}$, Krzysztof Kuczewski ${ }^{1}$ \\ ${ }^{1}$ Wroclaw University of Environmental and Life Sciences, Institute of Environmental Engineering, pl. Grunwaldzki 24a, \\ 50-365 Wroctaw, Poland \\ ${ }^{2}$ Wroclaw University of Science and Technology, Department of Machine Tools and Mechanical Technologies, Eukasiewicza 5, \\ 50-370 Wroctaw, Poland \\ ${ }^{3}$ Wroclaw University of Science and Technology, Department of Advanced Material Technologies, Smoluchowskiego 21, 50-372 \\ Wroctaw, Poland \\ "Corresponding author: e-mail: pawel.lochynski@up.wroc.pl
}

\begin{abstract}
The influence of organic additives on the process of surface electropolishing of AISI 304 type steel was determined. Additives were selected in initial potentiodynamic tests pursuant to the plateau analysis on the current/potential curves. The assessment of the operational effectiveness of additives consisted in determining the relationship between surface gloss after electropolishing and the mass loss of the sample and in determining surface roughness. The applied electropolishing bath consisted of a mixture of concentrated acids: $\mathrm{H}_{3} \mathrm{PO}_{4}$ and $\mathrm{H}_{2} \mathrm{SO}_{4}$, and the following organic additives were used: triethylamine, ethanolamine, diethanolamine, triethanolamine, diethylene glycol monobutyl ether and glycerol. The best electropolishing result, i.e. low roughness and high gloss of stainless steel surface with a relatively low mass loss of the sample at the same time were obtained for baths containing triethanolamine.
\end{abstract}

Keywords: electropolishing, organic additives, surface roughness, stainless steel.

\section{INTRODUCTION}

Scientific and industrial research on the electropolishing (EP) of stainless steel, conducted in various units, focus on the improvement of bath compositions, development of more beneficial process parameters and intensification of the process ${ }^{1-7}$. The modification of bath composition for baths, whose main components are: phosphoric $(\mathrm{V})$ and sulphuric(VI) acids, involves tests of surface active compounds. Their aim is to improve the smoothing of surface and to decrease bath contamination. Beneficial results may be obtained if these compounds are absorbed in indentations that exist on the surface of stainless stee $\mathrm{l}^{8-9}$. The applied additives should also prolong the period of operation of the bath, i.e. improve the economic aspect of the process.

Currently, the most commonly used additive that improves the gloss and smoothening of the surface in the electropolishing process, is glycerol. It is applied in the electrochemical processing of various metals and alloys: titanium, cobalt, niobium, copper, palladium, aluminium, zirconium, chromium and stainless steels ${ }^{10-12}$. Its content in electropolishing baths varies within a wide range, depending on the applied technology and it depends on numerous factors, e.g.: bath composition, process conditions, type of the processed metal and the expected results. The concentration of glycerol in the bath may reach even up to $35 \%$ wt.

Examples of bath additives used in the stainless steel electropolishing process, described in scientific and patent literature are presented in Table 1.

Numerous authors emphasise the positive influence of organic additives on the smoothening of stainless steel surface in the electropolishing process. However, literature does not provide information that would allow to compare the efficiency of baths containing the most commonly used additives, i.e. glycerol and mono-, diand triethanolamines with baths without such organic additives. Based on the review for presented research triethanolamine (TEA), triethylamine (TRE), ethanolamine (MEA), diethanolamine (DEA), glycerol (GLR) and diethylene glycol monobutyl ether, known as butyldiglycol (BDG) were selected for comparative tests. The latest two organic compounds (GLR and BDG) were listed as organic additives to electropolishing in the description of Best Available Techniques in the "Reference Document on Best Available Techniques for the Surface Treatment of Metals and Plastics"20. Our study focused on the improvement of surface properties of 304 stainless steel parts. The main objective of the study was to obtain better or faster effects of smoothing the surface samples after electrochemical treatment in baths that contained selected organic additives with a simultaneous decrease of the mass loss of the samples. Reducing the sample mass loss plays an important role in industrial practice and could significantly limit the contamination of electropolishing baths with ions of iron, chromium and nickel. On the one hand, lower bath contamination results in savings in power consumption during electropolishing, while on the other hand it brings benefits in form of cleaner water after washing and lower consumption of chemicals in the course of wastewater neutralization. These environmental aspects urge to examine organic additives.

\section{EXPERIMENTAL PROCEDURES}

\section{Sample preparation}

Specimens $(90 \times 25 \times 1.5 \mathrm{~mm}$ with a $12 \mathrm{~mm}$-diameter hole located at $5 \mathrm{~mm}$ distance from the shorter edge of the sample) were cut-off from the cold rolled stainless steel plate (AISI 304). The samples were designated as 2B-surface finish. The chemical material composition was (wt.\%): $0.037 \mathrm{C}, 0.42 \mathrm{Si}, 0.057 \mathrm{~N}, 1.28 \mathrm{Mn}, 0.029$ P, $0.002 \mathrm{~S}, 18.13 \mathrm{Cr}, 8.04 \mathrm{Ni}$ and balance Fe. All the 
Table 1. Examples of bath additives used in the stainless steel electropolishing process, described in scientific and patent literature

\begin{tabular}{|c|c|c|}
\hline Organic additive & Bath type & Obtained results \\
\hline $\begin{array}{l}\geq 1 \text { wt.\% 2-amino-2-methyl- } \\
\text {-1-propanol }\end{array}$ & $\begin{array}{l}\left.\geq 1 \text { wt.\% nonoxidizing acid (e.g. } \mathrm{H}_{3} \mathrm{PO}_{4}\right) \text {, citric } \\
\text { acid, tartaric acid, oxalic acid, acetic acid, } \\
\text { gluconic acid, glycolic acid, succinic acid, etc., } \\
\mathrm{H}_{2} \mathrm{SO}_{4} \text { and/or HF }\end{array}$ & $\begin{array}{l}\text { Efficient electropolishing of stainless steel, esp. after } \\
\text { welding and improvement of stainless steel corrosion } \\
\text { resistant }{ }^{14}\end{array}$ \\
\hline $\begin{array}{l}\geq 0.1 \text { wt. } \% \text { triethanolamine, } \\
\text { diethanolamine and/or } \\
\text { monoethanolamine }\end{array}$ & $\begin{array}{l}\geq 0.1 \text { wt. } \% \geq 1 \text { of } \mathrm{H}_{3} \mathrm{PO}_{4} \text {, citric acid, tartaric acid, } \\
\text { oxalic acid, acetic acid, gluconic acid, glycolic } \\
\text { acid, succinic acid, } \mathrm{H}_{2} \mathrm{SO}_{4} \text {, and their salt with } \\
\mathrm{Na}, \mathrm{K} \text {, and ammonium }\end{array}$ & $\begin{array}{l}\text { The electrolytic solution also improves corrosion } \\
\text { resistance of stainless steel }{ }^{15}\end{array}$ \\
\hline 3 wt. $\%$ triethanolamine & $\begin{array}{l}\mathrm{H}_{3} \mathrm{PO}_{4} 51 \text { wt. } \% \\
\mathrm{H}_{2} \mathrm{SO}_{4} 35 \text { wt. } \%\end{array}$ & $\begin{array}{l}\text { After EP of } 304 \text { stainless steel pitting potential in } 0.5 \mathrm{M} \\
\mathrm{NaCl} \text { solution increases up to } 0.5 \mathrm{~V}_{\mathrm{SCE}} \text {. Both laboratory } \\
\text { and industrial electrochemical treatment resulted in } \\
\text { consistent test results }^{16}\end{array}$ \\
\hline $\begin{array}{l}2.27 \text { vol.\% ethanoloamine } \\
\text { or diethanolamine or } \\
\text { triethanolamine }\end{array}$ & $\begin{array}{l}\mathrm{H}_{3} \mathrm{PO}_{4} 56.82 \text { vol. } \% \\
\mathrm{H}_{2} \mathrm{SO}_{4} 40.91 \text { vol. } \%\end{array}$ & $\begin{array}{l}\text { Hull cell studies indicated that best reflectance related to } \\
\text { minimum electrical power consumption were obtained } \\
\text { after EP with ethanoloamine }\end{array}$ \\
\hline 25 or 35 vol. $\%$ glycerol & $\mathrm{H}_{3} \mathrm{PO}_{4}$ and $\mathrm{H}_{2} \mathrm{SO}_{4}$ (volume ratios: $3: 2$ and $2: 1$ ) & $\begin{array}{l}\text { The bath temperature and EP time were highlighted as } \\
\text { the main factors affecting Ra after treatment, but current } \\
\text { density was examined only in the range } 0.5-1.0 \mathrm{~A} / \mathrm{cm}^{2} \text {. } \\
\text { The glycerol content and current density distinguished by } \\
\text { the significantly lower impact in the levelling the surface } \\
\text { compared to the main factors }\end{array}$ \\
\hline 10 vol. \% glycerol & $\begin{array}{l}\mathrm{H}_{3} \mathrm{PO}_{4} \text { and } \mathrm{H}_{2} \mathrm{SO}_{4} \\
\text { (volume rations: } 5: 5 / 6: 4 / 7: 3 \text { ) } \\
\text { Water content: } 0 / 10 / 20 / 30 \text { (vol.\%) }\end{array}$ & $\begin{array}{l}\text { Optimal conditions: } 6: 4 \text { acids ratio, } 85 \pm 10^{\circ} \mathrm{C}, 0.5 \text { to } 1.0 \\
\mathrm{~A} / \mathrm{cm}^{2}, 3-5 \text { min EP time, addition of glycerol reduce } \\
\text { surface roughness but anticorrosive performance in the } \\
\mathrm{FeCl}_{3} \text { after } 72 \mathrm{~h} \text { is deteriorated }\end{array}$ \\
\hline 10 vol. \% glycerol & $\begin{array}{l}\mathrm{H}_{3} \mathrm{PO}_{4}: \mathrm{H}_{2} \mathrm{SO}_{4}: \text { DI water ratio } \\
60: 20: 10(\text { vol. } \%)\end{array}$ & $\begin{array}{l}\text { After EP treatment the passive films were thicker than } \\
\text { naturally-formed passive films. In addition EP improves } \\
\text { the surface biocompatibility and hemocompatibility. } \\
\text { Nevertheless influence of addition glycerol weren't tested } \\
\text { and evaluated }{ }^{19}\end{array}$ \\
\hline
\end{tabular}

samples were degreased with acetone, then washed in distilled water and named as-received. Later, the samples were pickled for 10 minutes in a solution composed of (wt.\%): $4 \mathrm{HF}, 20 \mathrm{HNO}_{3}$ and distilled water in the temperature $30 \pm 0.2^{\circ} \mathrm{C}$.

\section{Experimental circuit}

The electropolishing process was carried out in a glass vessel of a volume of $400 \mathrm{~cm}^{3}$. The circuit consisted of: two cathodes and one anode (workpiece), a glass paddle stirrer, a thermometer, a thermostat Haake DC10 (Haake, Karlsruhe, Germany) with a spiral cooler, a power supply unit PS3010L (Velleman, Gavere, Belgium) and a charge counter KP-034 (KP-Elektronika, Dzierzoniow, Poland). The anode and cathodes were of the same size and made of the same stainless steel plate. A constant distance between the electrodes $(20 \mathrm{~mm})$ was assumed for test purposes. The samples of a surface area of 20 $\mathrm{cm}^{2}$ were partly immersed in an electrolyte solution. The upper parts of samples were covered with Teflon tape, which allowed for a precise designation of the working area and eliminated the problem of uneven polishing on the border of the media: bath - air. The EP bath consisted of (wt.\%): 51 phosphoric acid, 35 sulfuric acid, 3 organic additives and balance water. The electropolishing process was carried out at a stirring speed in the range of 49-50 $\mathrm{rpm}$ at bath temperature $55 \pm 1^{\circ} \mathrm{C}$. Subsequently all the samples were washed with distilled water.

\section{Organic compounds used as bath additives in the elec- tropolishing process}

Table 2 shows the structural formulas and molecular weights of some of the compounds used as additives to the bath.

\section{Potentiodynamic tests}

Potentiodynamic tests were carried out in a tri-electrode system with use of SI 1286 potentiostat manufactured by Solartron. The tested electrode was 304 steel, reference electrode - saturated calomel electrode (SCE) and the counter electrode was a platinum electrode. The system was thermostated. The obtained data were analysed with use of CorrView software.

\section{Gloss measurements}

Surface gloss of 304 steel was measured with use of Elcometer $406 \mathrm{~L}$ reflectometer. The device is equipped with a LED light source of a constant light intensity and it enables the gloss measurement of flat surfaces at $20^{\circ}$ and $60^{\circ}$ angles. Measurements were taken by recording the intensity of light reflected from the analysed surface. The gloss value is directly proportional to the amount of reflected light. Before the commencement of measurements, the apparatus was calibrated with use of a certified calibration plate. The applied measurement units were Gloss Units within the range 0-2000 GU for the $20^{\circ}$ angle and $0-1000 \mathrm{GU}$ for the $60^{\circ}$ angle. For the purposes of the conducted tests it was decided to measure sample gloss for the measurement angle of $20^{\circ}$, which is suitable for glossy surfaces.

\section{Surface roughness measurements}

Roughness was measured with use of surface profiler Form Talysurf 120L manufactured by Taylor Hobson Limited. Measurement was taken with use of connection method with a needle with a conical diamond tip, of an opening angle of $90^{\circ}$ and tip rounding radius of $2 \mu \mathrm{m}$. The length of the measured section $\lambda \mathrm{c}$ was $0.8 \mathrm{~mm}$. The surface profiler was controlled by Dell OptiPlex GX110 computer equipped with ULTRA software, rev. 6.0. Surface roughness assessment was based on the amplitude 
Table 2. Organic additives used in tests on the electropolishing of AISI 304 steel

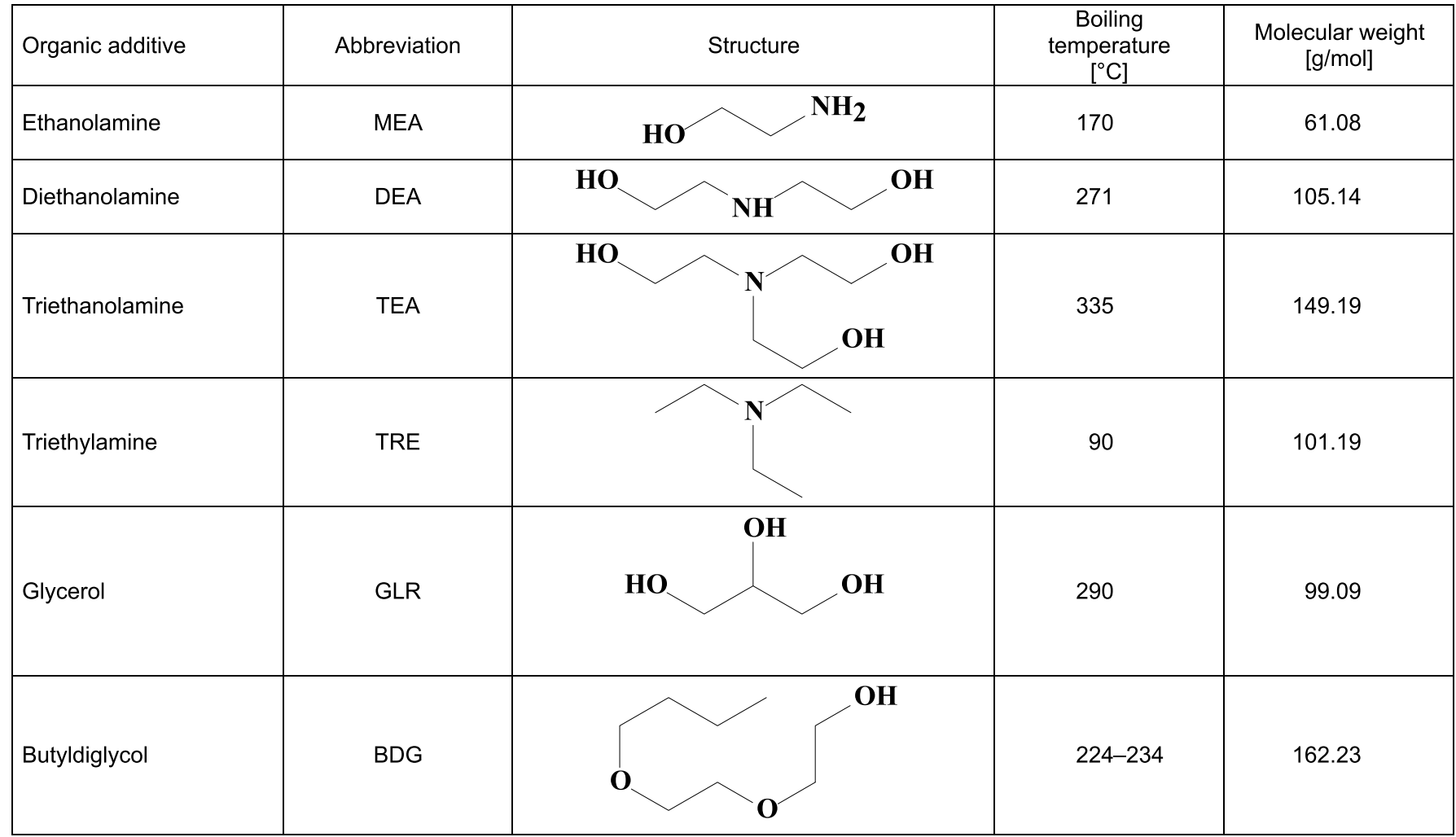

parameter $\mathrm{R}_{\mathrm{a}}$ (arithmetic mean of the absolute departures of the roughness profile from the mean line) and $\mathrm{R}_{\mathrm{sk}}$ skew (the asymmetry of the topography height distribution, showing if the holes or the hills are dominating features of the surface) and $\mathrm{R}_{\mathrm{ku}}$ kurtosis (quantifies the width of the peak of the height histogram indicating how much the majority of the surface is close to the main plane). A summary list of the specified parameters allows for a more accurate description of surface topography ${ }^{\mathbf{2 1 - 2 3}}$.

\section{RESULTS AND DISCUSSION}

\section{Potentiodynamic tests}

In order to determine the influence of various organic additives on I-V curves, potentiodynamic tests were conducted for electropolishing solutions, which contained selected organic compounds. Initial tests for phosphoric and sulphuric acid bath without additives (Fig. 1A) and with the addition of triethanolamine (Fig. 1B), conducted at a scanning rate from 0.25 to $10 \mathrm{mV} / \mathrm{s}$ allowed us to determine that the potential change rate of $1 \mathrm{mV} / \mathrm{s}$ enables to precisely determine the current parameters of the occurrence of plateau in a relatively short measurement period.

Figure 2 shows the anodic curves obtained for the following bath composition (wt.\%): $51 \mathrm{H}_{3} \mathrm{PO}_{4}, 35$ $\mathrm{H}_{2} \mathrm{SO}_{4}, 3$ - addition of organic compound, $11 \mathrm{H}_{2} \mathrm{O}$. Bath temperature was $55^{\circ} \mathrm{C}$. For base composition of the bath (without added organic compounds) the plate$a u$ occurred in the potential range: 1.55-1.9 $\mathrm{V}_{\mathrm{SCE}}$ and the corresponding current densities from $2.35 \cdot 10^{-2}$ to $2.50 \cdot 10^{-2} \mathrm{~A} / \mathrm{cm}^{2}$. The addition of triethylamine to the phosphoric and sulphuric bath changed this value only slightly $\left(2.15-2.28 \cdot 10^{-2} \mathrm{~A} / \mathrm{cm}^{2}\right)$ which demonstrates its low activity. In the presence of triethanolamine, the pla-
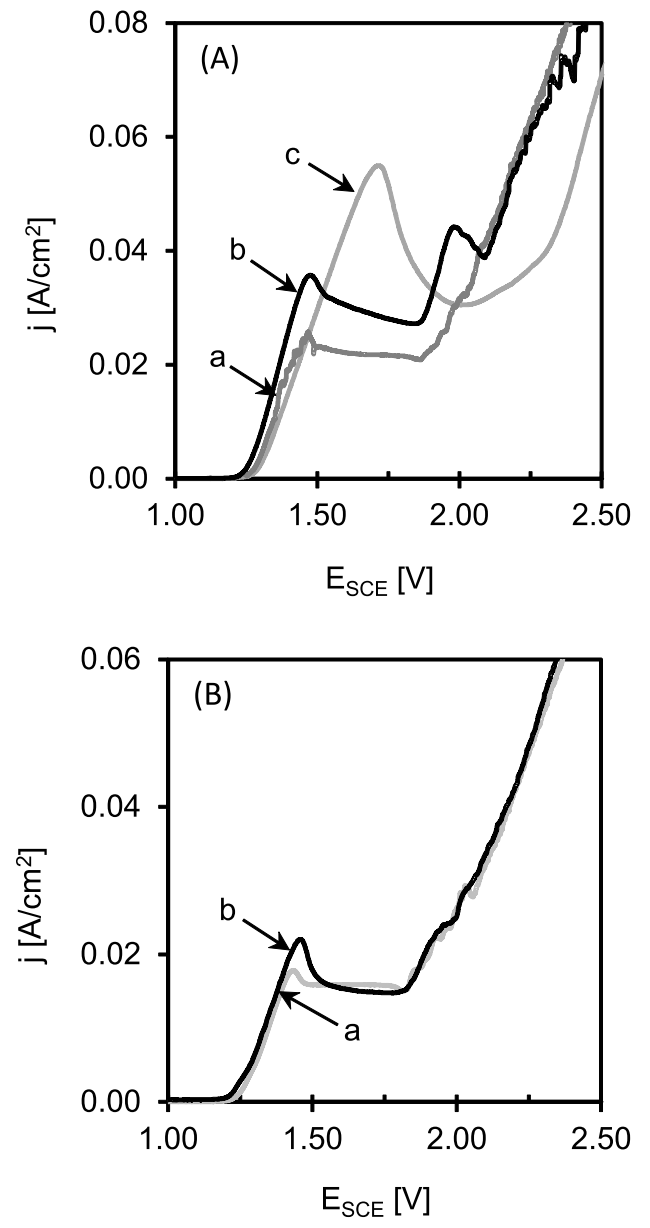

Figure 1. Anode polarisation curves obtained at different scanning rates: (a) $0.25 \mathrm{mV} / \mathrm{s}$; (b) $1.0 \mathrm{mV} / \mathrm{s}$; (c) $10 \mathrm{mV} / \mathrm{s}$. Baths consisted of (wt.\%): (A) 53\% phosphoric and $36 \%$ sulphuric acids and balance water $\left(\mathrm{T}=45^{\circ} \mathrm{C}\right)$; (B) $51 \%$ phosphoric and $35 \%$ sulphuric acids with the addition of $3 \%$ triethanolamine and balance water $\left(\mathrm{T}=55^{\circ} \mathrm{C}\right)$ 
teau level decreased to the value of $1.59 \cdot 10^{-2} \mathrm{~A} / \mathrm{cm}^{2}$ and for monoethanolamine to $1.60 \cdot 10^{-2} \mathrm{~A} / \mathrm{cm}^{2}$. One might conclude that all of the selected compounds, apart from triethylamine are active as additives to electropolishing baths (Fig. 2).

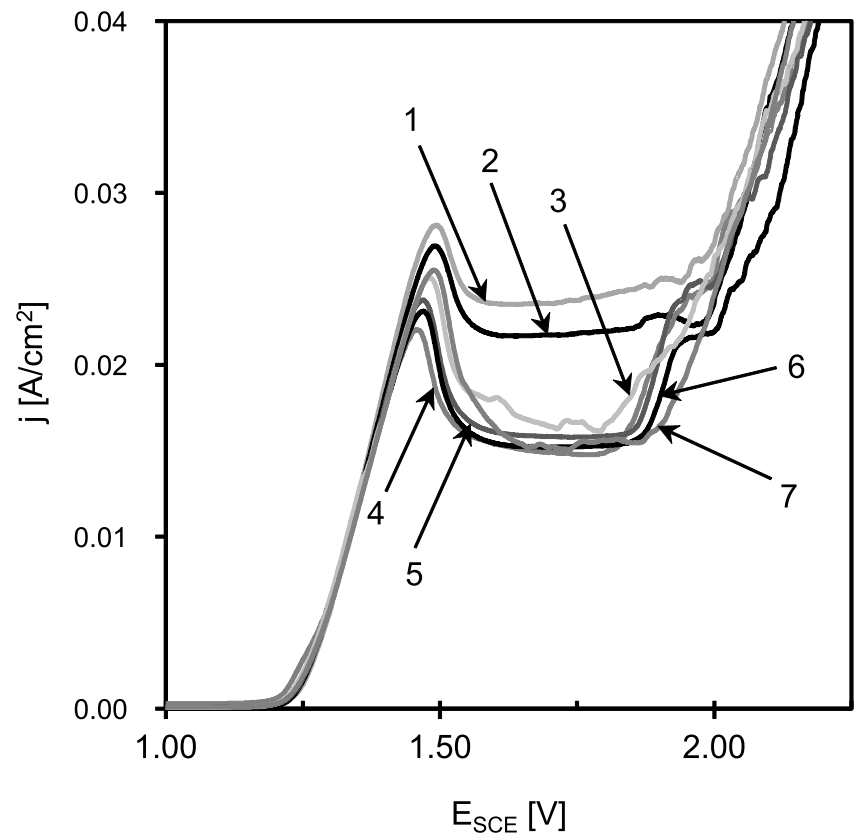

Figure 2. Anodic curves in a mixture of: (1) phosphoric acid, sulfuric acid and balance water (53:36:11 by wt.\%) or phosphoric acid, sulfuric acid, balance water and selected organic additives (51:35:11:3 by wt. $\%$ )

(2) triethylamine, (3) glycerol, (4) triethanolamine, (5) ethanolamine, (6) diethanolamine, (7) butyldiglycol; scan rate $1 \mathrm{mV} / \mathrm{s}, \mathrm{T}=55^{\circ} \mathrm{C}$

\section{Surface modification}

In order to evaluate the role of the used bath additives, electropolishing was conducted, followed by the determination of the mass loss and change in gloss of the samples (Table 3). It was demonstrated that the used additives generally decrease mass loss. This will result in lower contamination of the phosphoric and sulphuric bath, but it may also point to decreased intensity of the electropolishing process. The mass loss in samples subject to electropolishing in bath containing glycerol was $27 \%$ lower, and in bath containing triethanolamine $-17 \%$ lower than in bath with base composition (without additives). Only triethylamine caused a $24 \%$ increase in mass loss.

The gloss of samples subject to electropolishing in bath without additives was $890( \pm 20)$ GU. TEA slightly improved gloss: in the same electropolishing conditions
$900( \pm 20)$ GU were measured. Glycerol has an inadequate effect - the gloss was decreased to $680( \pm 10)$ GU.

Electropolishing of samples for 6 minutes at current density $0.3 \mathrm{~A} / \mathrm{cm}^{2}$ in baths containing the addition of BDG or TEA resulted in similar mass losses, respectively: $43.4 \mathrm{mg} / \mathrm{cm}^{2}$ and $44.6 \mathrm{mg} / \mathrm{cm}^{2}$. However, the measured gloss values of both samples were quite different. TRE, on the other hand, enables to obtain high surface gloss $(1045 \mathrm{GU})$ for electropolishing for 6 minutes at current density of $0.3 \mathrm{~A} / \mathrm{cm}^{2}$, but with a simultaneous high mass loss $\left(67.0 \mathrm{mg} / \mathrm{cm}^{2}\right)$. Additionally, its relatively low boiling temperature of $90^{\circ} \mathrm{C}$ significantly limits the possibilities to apply this compound on an industrial scale.

Ethylendiamine, diethanolamine and triethanolamine have a similar influence on the gloss and mass loss of the sample during electropolishing in phosphoric and sulphuric bath. The best gloss effect with a simultaneous smallest mass loss of the sample $-20.2 \mathrm{GU} \cdot \mathrm{cm}^{2} / \mathrm{mg}$ was obtained for triethanolamine. From the practical point of view, a major advantage of this compound is the fact that its boiling temperature is the highest among the applied additives.

In the initial stage of electropolishing, the baths with base composition are changing their color. In baths without organic additives, after the flow of 1-2.5 $\mathrm{Ah} /$ $\mathrm{dm}^{3}$ volume of the baths, metal ions originating from anodic dissolution of 304 steel changed the colour of transparent bath to brown. In the presence of MEA, DEA, TEA or GLR the colour of the bath turned green. The bath containing BDG was initially yellow, and then it darkened and became dark green. The addition of TRE initially dyed the bath brown, and, after several hours of operation - dark green. This is evidence of slow complexing of iron ions.

Electropolishing of 304 steel in in bath with base composition at a current density of $0.3 \mathrm{~A} / \mathrm{cm}^{2}$ and a specific charge input of $0.02 \mathrm{Ah} / \mathrm{cm}^{2}(\mathrm{t}=4 \mathrm{~min})$ reduce the sample roughness to $R_{a}=0.12 \mu \mathrm{m}$ (Table 4 ). In the same electropolishing conditions, improved surface smoothness of AISI 304 steel was obtained after the application of bath containing TEA $\left(\mathrm{R}_{\mathrm{a}}=0.095 \mu \mathrm{m}\right)$. GLR addition proved much less effective $\left(\mathrm{R}_{\mathrm{a}}=0.14 \mu \mathrm{m}\right)$. Increasing the electric charge twice (to $\mathrm{q}=0.04 \mathrm{Ah} / \mathrm{cm}^{2}$ ) did not result in improved roughness of samples subject to electropolishing in bath without organic additives. However, as the time of electropolishing increased to $8 \mathrm{~min}$, the smoothness of samples processed in baths containing TEA and GLR improved, respectively, to the values $\mathrm{R}_{\mathrm{a}}=0.079 \mu \mathrm{m}$ and $\mathrm{R}_{\mathrm{a}}=0.090 \mu \mathrm{m}$ for $\mathrm{q}=0.04 \mathrm{Ah} / \mathrm{cm}^{2}$.

Surface roughness assessment based only on the $\mathrm{R}_{\mathrm{a}} \mathrm{pa}$ rameter is quite often insufficient, as this parameter only

Table 3. Mass loss and changes in the surface gloss of 304 steel after electropolishing in phosphoric and sulphuric bath with the addition of 3 wt. $\%$ organic additives $\left(q=0.03 \mathrm{Ah} / \mathrm{cm}^{2}, j=0.3 \mathrm{~A} / \mathrm{cm}^{2}, \mathrm{t}=6 \mathrm{~min}, \mathrm{~T}=55^{\circ} \mathrm{C}\right)$

\begin{tabular}{|l|c|c|c|}
\hline \multirow{2}{*}{ Organic additive } & Abbreviation & \multicolumn{2}{|c|}{ After electropolishing } \\
\cline { 2 - 4 } & - & $\begin{array}{c}\text { Gloss } \\
{[\mathrm{GU}]}\end{array}$ & $\begin{array}{c}\text { Mass loss } \\
{\left[\mathrm{mg} / \mathrm{cm}^{2}\right]}\end{array}$ \\
\hline None & TEA & $890( \pm 10)$ & 54.1 \\
\hline Triethanolamine & DEA & $800( \pm 20)$ & 44.6 \\
\hline Diethanolamine & MEA & $880( \pm 20)$ & 46.8 \\
\hline Ethanolamine & GLR & $680( \pm 10)$ & 48.0 \\
\hline Glycerol & TRE & $1045( \pm 20)$ & 39.7 \\
\hline Triethylamine & BDG & $410( \pm 10)$ & 67.0 \\
\hline Butyldiglycol & & 17.5 & 17.1 \\
\hline
\end{tabular}


Table 4. Surface roughness after: pickling in a solution composed of $\mathrm{HF}, \mathrm{HNO}_{3}$ and $\mathrm{H}_{2} \mathrm{O}(4: 20: 76$ by wt. $\%), \mathrm{T}=30^{\circ} \mathrm{C}(\mathrm{A}) \mathrm{t}=10$ min; electropolishing in $\mathrm{H}_{3} \mathrm{PO}_{4}, \mathrm{H}_{2} \mathrm{SO}_{4}, \mathrm{H}_{2} \mathrm{O}(53: 36: 11$ by wt.\%) and with addition of selected organic additive (51:35:11:3 by wt.\%), $\mathrm{T}=55^{\circ} \mathrm{C}$ (B) $\mathrm{j}=0.3 \mathrm{~A} / \mathrm{cm}^{2}, \mathrm{t}=4 \mathrm{~min}$; (C) $\mathrm{j}=0.3 \mathrm{~A} / \mathrm{cm}^{2}, \mathrm{t}=6 \mathrm{~min}$; (D) $\mathrm{j}=0.4 \mathrm{~A} / \mathrm{cm}^{2}, \mathrm{t}=6 \mathrm{~min}$

\begin{tabular}{|c|c|c|c|c|c|c|}
\hline \multirow{3}{*}{ Surface treatment } & \multicolumn{6}{|c|}{ Organic additive } \\
\hline & \multicolumn{2}{|c|}{ None } & \multicolumn{2}{|c|}{ Glycerol } & \multicolumn{2}{|c|}{ Triethanolamine } \\
\hline & $\mathrm{R}_{\mathrm{a}}[\mu \mathrm{m}]$ & Sd & $\mathrm{R}_{\mathrm{a}}[\mu \mathrm{m}]$ & Sd & $\mathrm{R}_{\mathrm{a}}[\mu \mathrm{m}]$ & $S d$ \\
\hline (A) Pickling & 0.38 & 0.005 & 0.40 & 0.017 & 0.38 & 0.012 \\
\hline (B) Electropolishing $0.02 \mathrm{Ah} / \mathrm{cm}^{2}$ & 0.12 & 0.012 & 0.14 & 0.017 & 0.095 & 0.006 \\
\hline (A) Pickling & 0.35 & 0.010 & 0.36 & 0.009 & 0.36 & 0.010 \\
\hline (C) Electropolishing $0.03 \mathrm{Ah} / \mathrm{cm}^{2}$ & 0.10 & 0.005 & 0.10 & 0.005 & 0.090 & 0.006 \\
\hline (A) Pickling & 0.35 & 0.010 & 0.36 & 0.009 & 0.36 & 0.005 \\
\hline (D) Electropolishing $0.04 \mathrm{Ah} / \mathrm{cm}^{2}$ & 0.12 & 0.012 & 0.090 & 0.008 & 0.079 & 0.006 \\
\hline
\end{tabular}

reflects the arithmetic mean of the height of all points in the topography within the analysed measurement section. The combination of the $\mathrm{R}_{\mathrm{a}}, \mathrm{R}_{\mathrm{sk}}$ and $\mathrm{R}_{\mathrm{ku}}$ parameters has a major significance in terms of the surface resistance to the dirt covering. The $\mathrm{R}_{\mathrm{ku}}$ parameter value close to 3 represents a Gaussian distribution, while higher and

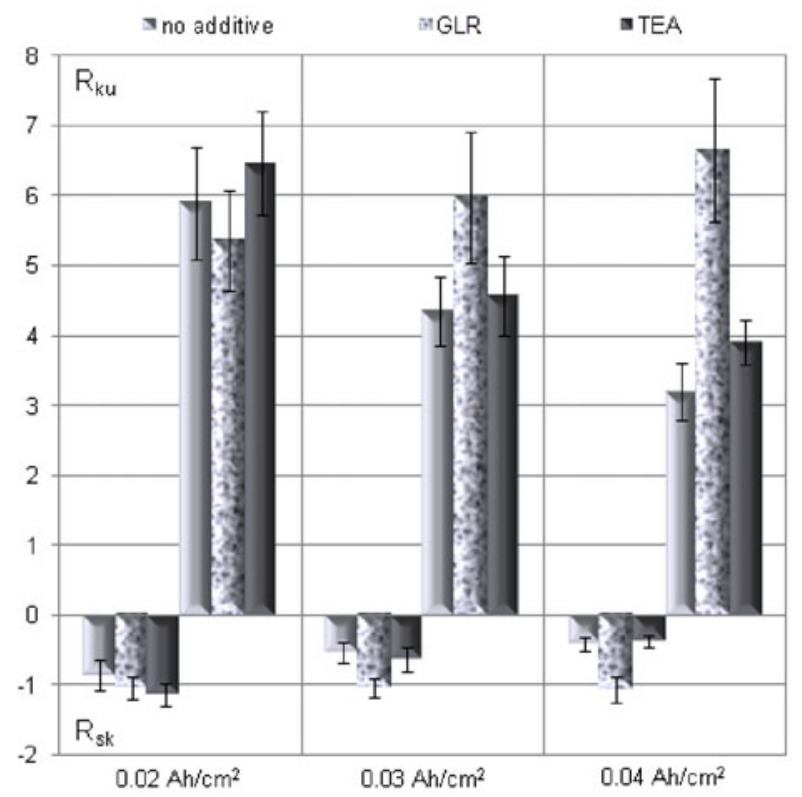

Figure 3. The average values and standard deviation bars of the $R_{k u}$ and $R_{s k}$ roughness parameters for the investigated samples electropolished in the baths with glycerol or triethanolamine and without organic additives

lower values gradually reflect, respectively, narrower and wider distribution. On the other hand, the approximation of the negative $\mathrm{R}_{\mathrm{sk}}$ value to 0 demonstrates that pores are no longer dominant surface features in relation to the hills. Electropolishing with an addition of TEA improved surface smoothness most effectively, which is illustrated by a progressive decrease of $R_{a}$ up to 0.079 $\mu \mathrm{m}$ and $\mathrm{R}_{\mathrm{ku}}$ to 3.9 and a simultaneous increase of $\mathrm{R}_{\mathrm{sk}}$ to -0.37 (Fig. 3).

\section{CONCLUSIONS}

The present investigation has demonstrated that the selection of additives to the electropolishing process may be initially verified by observing the changes in the current/potential characteristics in potentiodynamic tests. Lowering the plateau level (and increasing the range of potentials in which it occurs) constitutes proof of the activity of organic compounds and their adsorption on the electropolished surface. Considering the very high boiling temperature, relatively low mass loss during electropolishing, and the simultaneously obtained high gloss and low surface roughness, triethanolamine represents an optimal additive for electropolishing. The comparison of mass loss and gloss increase in samples from bath containing triethanolamine demonstrated that much better results per surface area unit of the electropolished surface were obtained $\left(20.1 \mathrm{GU} \cdot \mathrm{cm}^{2} / \mathrm{mg}\right)$ in comparison to glycerol $\left(17.5 \mathrm{GU} \cdot \mathrm{cm}^{2} / \mathrm{mg}\right)$ and to the control sample electropolished in bath with base composition without additive $\left(16.5 \mathrm{GU} \cdot \mathrm{cm}^{2} / \mathrm{mg}\right)\left(\mathrm{q}=0.03 \mathrm{Ah} / \mathrm{cm}^{2}\right.$, $\left.\mathrm{j}=0.3 \mathrm{~A} / \mathrm{cm}^{2}, \mathrm{t}=6 \mathrm{~min}, \mathrm{~T}=55^{\circ} \mathrm{C}\right)$. The application of triethanolamine also contributes to a smooth surface. The addition of glycerol requires a prolonged time for reaching similar electropolishing results.

\section{LITERARTURE CITED}

1. Nazneen, F., Galvin, P., Arrigan, D., Thompson, M., Benvenuto, P. \& Herzog, G. (2012). Electropolishing of medicalgrade stainless steel in preparation for surface nano-texturing. J. Solid State Electroch. 16(4), 1389-1397. DOI: 10.1007/ s10008-011-1539-9.

2. Lai, J.J. \& Lee, S.J. (2003). The effects of electropolishing (EP) process parameters on corrosion resistance of 316L stainless steel. J. Mater. Process. Technol. 140, 206-210. DOI: 10.1016/S0924-0136(03)00785-4.

3. Jullien, C., Benezech, T., Carpentier, B., Lebret, V. \& Faille, C. (2003). Identification of surface characteristics relevant to the hygienic status of stainless steel for the food industry. $J$. Food. Eng. 56, 77-87. DOI: 10.1016/S0260-8774(02)00150-4.

4. Baron, A., Simka, W., Nawrat, G. \& Szewieczek, D. (2008). J. Achiev. Mat. Manuf. Eng. 31, 197-202. Electropolishing and chemical passivation of austenitic steel. Retrieved December 10, 2015, from Journal AMME database on the World Wide Web: http://www.journalamme.org

5. Hryniewicz, T., Rokicki, R. \& Rokosz, K. (2008). Surface characterization of AISI 316L biomaterials obtained by electropolishing in a magnetic field. Surf. Coat. Tech. 202, 1668-1673. DOI: 10.1016/j.surfcoat.2007.07.067.

6. Lochyński, P., Łyczkowska, E., Pawełczyk, A. \& Szczygieł, B. (2012). Effect of bath exploitation on steel electropolishing process efficiency. Przem. Chem., 91, 846-848.

7. Kao, P.S. \& Hocheng, H. (2003). Optimization of electrochemical polishing of stainless steel by grey relational analysis J. Mater. Process. Technol. 140, 255-259. DOI: 10.1016/S09240136(03)00747-7.

8. Bhuyan, A., Gregory, B., Lei, H., Yuen Yee, S. \& Gianchandani, Y.B. (2005). Pulse and DC electropolishing of stainless steel for stents and other devices. In Proceedings of IEEE Sensors. 4th IEEE Conference on Sensors, 31 October - 3 November 2005 (pp. 314-317). Irvine, CA, USA. Publisher IEEE. DOI: 10.1109/ICSENS.2005.1597699 Sensors IEEE, 314-317. 
9. Hocheng, H., Kao, P.S. \& Chen, Y.F. (2001). Electropolishing of 316L stainless steel for anticorrosion passivation. J. Mater. Eng. Perform. 10(4), 414-418. DOI: 10.1361/105994901770344827.

10. Shieh, J.M., Liu, S.H. \& Dai, B.T. (2006). U.S. Patent No. 20060070888.

11. Baldin, A.V., Matvienko, A.F., Krivoshchapova, E.M., Arbuzov, V.L. \& Klotsman, S.M. (1985). U.S.S.R. Patent No. 1171570.

12. Andreshak, J.C., Datta, M., Romankiw, L.T., Vega, L.F. (1991). U.S. Patent No. 5066370.

13. Lin, C.C., Hu, C.C. \& Lee, T.C. (2009). Electropolishing of 304 stainless steel: Interactive effects of glycerol content, bath temperature, and current density on surface roughness and morphology. Surf. Coat. Technol. 204, 448-454. DOI: 10.1016/j. surfcoat.2009.08.005.

14. Taguchi, C. (2007). Japan Patent No. 2007332416 (A).

15. Taguchi, C. (2007). Japan Patent No. 2007231413 (A).

16. Lochyński, P., Łyczkowska, E., Szczygiel, B. \& Kuczewski, K. (2014). Pitting corrosion of pickled and electropolished Cr-Ni stainless steel. Przem. Chem. 93(5), 762-765. DOI: 10.12916/ przemchem.2014.762.

17. Mohan, S., Jayashree, G. \& Vasudevan, T. (2000). Electropolishing of stainless steel. Bull. Electrochem. 16(9), 388-391.

18. Lin, C.C. \& Hu, C.C. (2008). Electropolishing of 304 stainless steel: Surface roughness control using experimental design strategies and a summarized electropolishing model. Electrochim. Acta 53, 3356-3363. DOI: 10.1016/j.electacta.2007.11.075.

19. Habibzadeh, S., Li, L., Shum-Tim, D., Davis, E.C. \& Omanovic, S. (2014). Electrochemical polishing as a 316L stainless steel surface treatment method: Towards the improvement of biocompatibility. Corrosion Sci. 87, 89-100. DOI: 10.1016/j. corsci.2014.06.010.

20. European Commission. (2006). Integrated Pollution Prevention and Control, Reference Document on Best Available Techniques for the Surface Treatment of Metals and Plastics, 1-546.

21. Iwan, A., Boharewicz, B., Tazbir, I., Sikora, A., Maliński, M., Chrobak, Ł. \& Madej, W. (2015). Laser Beam Induced Current Technique of Polymer Solar Cells Based on New Poly(Azomethine) or Poly(3-Hexylthiophene). Chem. Sci. Rev. Lett. 4(14), 597-607. Database on the World Wide Web: http:// www.chesci.com/articles/csrl/v4i14/20_CS12204605.pdf

22. Kamble, S.S., Sikora, A., Pawar, S.T., Kambale, R.C., Maldar, N.N. \& Deshmukh, L.P. (2015). Morphology reliance of cobalt sulfide thin films: A chemo-thermo-mechanical perception. J. Alloy. Compd. 623, 303-314. DOI: 10.1016/j. jallcom.2015.01.097.

23. Lochynski, P., Sikora, A. \& Szczygiel, B. (2016): Surface morphology and passive film composition after pickling and electropolishing, Surface Engineering, DOI: 10.1080/02670844.2016.1238189. 